\title{
Visual Aids and Multimedia in Second Language Acquisition
}

\author{
Noha Halwani ${ }^{1}$ \\ ${ }^{1}$ English Language Institute, King Abdulaziz University, Jeddah, Saudi Arabia \\ Correspondence: Noha Halwani, English Language Institute , King Abdulaziz University, P. O. Box 80200, \\ Jeddah, Post Code 21589, Saudi Arabia. E-mail: nhalawani@kau.edu.sa
}

Received: March 1, 2017 Accepted: May 20, 2017 Online Published: May 26, 2017

doi: 10.5539/elt.v10n6p53 URL: http://doi.org/10.5539/elt.v10n6p53

\begin{abstract}
Education involves more than simply passing the final test. Rather, it is the process of educating an entire generation. This research project focused on language learners of English as a Second Language. This action research was conducted in an ESL classroom in H. Frank Carey High School, one of five high schools in the Sewanhaka Central District of Nassau County. The research project explored the question: "Can visual aids improve English language acquisition in reading and writing for a beginner ESL?" The data analyzed were log observation sheets, pull-out focus groups, checklists, and surveys of students. The basic findings were that reading and writing improved when teachers used visual aids, especially when teachers pulled students out of the classroom for individualized instruction. Therefore, the study concluded that the use of visual aids and multimedia can help the students to absorb the content and become interactive in the classroom with no fear of giving wrong answers or, of having trouble being a participant in the class because of shyness.
\end{abstract}

Keywords: pull out, multimedia, integration, analysis, adaptability, education, visual aids, English as a second language

\section{Introduction}

\subsection{Introduce the Problem}

In our present day and age, we are encountering a huge amount of widespread technology around us. This technology exists everywhere including banks, courts, schools, and even small stores. We cannot simply abandon such a commodity since it has become an integral part of our lives. Technology also has had a major impact on education. For instance, it can facilitate the learning process and make it more effective. The teachers can help student's learning by monitoring and evaluating their performance. Arguably, the teacher has the capacity to create an interesting lesson through the computer, and technology is useful for teachers to introduce the lesson and give it an added value with better illustrations.

From my personal experience as a previous ESL student, the visual aids are so important for second language acquisition; they can be a tool to link words and their meanings. I remember when my ESL teacher illustrated the meaning of words such as the words 'carpenter' and 'farmer' by showing us pictures of them. I have been fortunate in having observation in the ESL class at Barack Obama School for other ESL teacher, and been given the chance to teach a Math lesson to first grade, ESL students. I had implemented in my lesson how visuals could help students' assimilation by explaining the lesson of "symbols greater than, less than" using a picture of a shark's open mouth. The results were amazing. The student became more interactive, and the lesson more comprehensible. Thus, I realize that multimedia can immensely help ESL student.

\subsection{Framing the Research Question}

From my own point of view, multimedia can help students overcome their obstacles they face in learning. It can also motivate their cognitive thinking and improve their communication skills. COnsequently, my research question is: How can visual aids improve English language acquisition in reading and writing for beginner ESL high school students?

\subsection{Rationale for the Study}

There are two reasons that have driven me to research this topic. First, I am deeply saddened by the teaching methods that my country uses in delivering English language lessons at public schools. The schools do not have the appropriate equipment such as posters, bulletin board, class library, smart boards and computers to teach 
English. In addition, some teachers do not even attempt to integrate visual aids in their class; they rely on what the textbook provides. Second, it is my passion to learn of possibilities to improve students' assimilation by integrating multimedia into the ESL classroom. I have chosen to focus on writing and reading skills and whether the teachers obtain an advantage from using this technology. The uses of multimedia and visual aids can have a positive effect on the students' comprehension of content, helping them to overcome learning difficulties through the use of videos, photos, websites, Smart Boards, and other technologies. Being a former foreign student, I can say that acquiring and mastering reading and writing skills are very important for learners of English as a second language. Multimedia and visual aids help students to greatly improve their skills in mastering a foreign language. Technology has had a major impact on education. Nevertheless, it has some features that can improve the educational process such as:

- *It can facilitate the learning process and make it more effective.

- $\quad *$ The teachers can help student's learning by monitoring and evaluating their performance.

- *The teacher has the capacity to create an interesting lesson through the computer, and technology is useful for teachers to introduce the lesson and give it better illustrations.

Visual aids and multimedia are usually used as scaffolding for the students with different ways in different level (Van Staden, 2011). In a research study conducted by Henry and Simpson (2001) and focused on the importance of books and discussed the value of pictures for ESL studentsPicture books in social studies, language arts, reading, art, and math and science can be very useful. Additionally, the role of visual aids and how it is used can be highly engaging in the educational structure to develop English as a second language. The studies showed how visual techniques are integrated into the educational setting for the pre-service and in-service teachers. The value of picture books:

- Value for ESL students: it is great for the ESL and special educational needs (SEN) students because it uses the visual-verbal connection.

- Interactivity: picture books have an advantage over videotapes, a popular visual resource used by classroom teachers, in that they are interactive.

- Brevity: picture books can be read in 15-30 minutes (average), leaving time for discussion, or another lesson activity afterword.(Al Tiyb, 2014; Mohr, 2004)

Many researchers search about how effective visual aids are. In article study conducted byPark (2000), he examines the best learning styles for a smaple of Asian students: (visual, auditory, sensory and motor and touch). In addition, it shows the students their strengths and offers ways for them to help themselves. Suggestions include diversification in the teaching methods commensurate with the students' learning style. In article research study conducted byAjayi (2008), it examined the ability of the media (video, pictures, cartoon...etc) to clarify the meaning of certain words. Also, the author explores the possibility of the media to improve the students' conversation, and the participation in the class. In the research study conducted byCooper (2002), the author examines the relationship between the student and visual source, and highlights the need to focus on the elements that affect its successful implementation. Second, the environment is examined, and how it could influence our interpretation of visual information, symbols, pictorial conventions, and skills in learning.

A research study conducted by van Berkel (2004), the author discusses English language beginners' level learners and how they lack the necessary prerequisites for a phonological strategy. It is claimed that, in spelling acquisition in English a second language (L2), a visual strategy must play an important role, and the importance of visual aids as strategies to improve the skill of spelling. In their study, Shaw, Baggett, and Salyer (2004) stress that computer technology can be incorporated into the ESL programs to improve students' motivation. Using visual thinking tools to extend students' thinking is effective. As an ESL teacher who observed and worked with kids from $\mathrm{K}-12$, just from the perspective of the teacher, that you are a monolingual teacher of students with visual impairments and don't speak English. What will you teach? How will you teach it? Where will you begin? One instructional approach to facilitate second-language learning for students with visual impairments is total physical response (TPR) (Asher, 1969). In the research study conducted by Conroy (1999), the author applied different ways to use TPR depending on students' ages, abilities, and language levels and the size of the group. From this research, it was concluded that it is recommended to utilize this method to use with ESL to improve students' proficiency. In the research article by Cunningham (1991), the possibility of improving students' education by using slide shows was explored. Also, the author examines whether it will stick in the student's mind or not. Additionally, in the article by Gorman and Eastman (2010), the authors recommended utlizing classroom activities for actively engaging students in analyzing visual images to improve their reading and 
writing skills.

Finally, in a research study conducted byTurner and Upshur (1995), the author studied the relationship between communicative effectiveness and grammatical accuracy. The result of implementing this program in a French school and what tools he used to examine it, were the focus of the article. To conclude my literature review, all these and other research pointed to the importance of the use of visual aids and its positive impact on stimulating students and how much it enriches the students' learning experience. This review also indicated the extent of facilitating the learning process through the use of multimedia and how multimedia improves the students' concentration and class participation.

\subsection{The Settings of the Study}

During the Fall semester, in 2013 I conducted my fieldwork in Frank Corey High School in Franklin Squire, Sewanthka Central School District. It is a school of about 1877 students who range from grade 7 to grade 12 . There are 180 ESL students, and the average class size is around 27 students. Ethnic differences create a diverse community: The student population is 30\% Hispanic, 30\% Haitian, 30\% Asian, and 10\% Miscellaneous. Most of the students do not qualify for free lunch, which means their families have medium or high incomes. In addition, 91\% of the students are proficient in English, which is good advantage. The remaining 9\% have limited English proficiency. I was placed in an upper-grade ESL classroom to do my observation.

\section{Method}

For my study, I used two data-collection tools: a time log observation sheet and a survey. I used the observation $\log$ (see Figure 1 - Appendix 1) to record students' attention for ten-minute intervals. I requested the teacher to avoid using any multi-media at the beginning of the first ten minutes of the lesson. Then, the teacher integrated pictures and mlti-media to see how much that affected the students. In addition, I used the survey as data collection but the teacher could not let me use her entire class to explore my theory. Instead she allowed me to pull out five students. I split the plan into two periods. I chose the lesson randomly; it was about Halloween. I gave the students the first lesson without using any media. Next, I taught the supplementary lesson with the same topic but with various types of multi-media: pictures, video, and the computer every student completed a survey, reproduced in figure 2 (Appendix 2), in which they indicated how much they enjoyed the lesson and whether the use of visual aids enhanced their understanding of the material. Thus, the future next step, I will focus on the ESL teacher's using multimedia materials to give instructions and explain the academic knowledge in reading and writing.

\section{Results}

The time log observation sheet revealed some interesting information about the ways the teachers and students interacted. I observed the teachers while they were using visual aids and how much that affected the instruction. I witnessed that the use of mlti-media helped ESL students to speak, read, write, and follow up the teacher's instruction. From figure 1 (Appendix 1) I found that the students in the first ten minutes were relatively quiet; they just copied what the teacher wrote on the board. As the time passed, however, the students became more interactive everytime the teacher integrated visual aids. I found that the more scaffolding you give to the students the more interaction you get. The survey results showed that $90 \%$ of the students liked to learn by using visual aids. In addition, the use of visual aids improved their self-confidence, comprehension, and concentration.

The results with the pulled out students were amazing: The students showed that they absorbed and participated more in the lesson that I taught with visual aids and technology. As second language learners of English, their sense of confidence about reading appeared to grow remarkably. It's difficult to generalize these findings to all ESL learners because it was a small group and limited time. Other benefits of using visual aids emerged from the survey given to the students. Using mlti-media to illustrate the lesson enabled the students to concentrate better. From Figure 1, I found that the students were more likely to participate when the class used visual aids. There were increased corporation and interaction among students and they were able to follow along step by step with their teacher. For example: I noticed the responses of Student \#2 (see Appendix 1) that at the beginning of the class he didn't feel confident at all. He only copied the notes that the teacher had written on the board because he did not understand what the teacher was taking about. Then, as the time went by, the teacher started using visual aids more and more. The log sheet showed that Student \#2 gained self-confidence gradually and became much more interactive, voluntarily speaking and reading as well. He wasn't lost or ashamed anymore of reading out loud and participating in the classroom discussion. He became much more aware of what he is going to talk about. Arguably, my observation of the teachers and students sparked my own view of the teaching process and how it is very important to attract students' attention and improve their concentration by scaffolding them using multi-media. The students became more flexible and collaborative. They could write much more thoroughly and 
confidently if they had watched background pictures, videos, and other multi-media aids. A delimitation of this action research is that in addition to the lack of multi-media, other variables could prevent students from writing in class even if they have some understanding of the topic. These variables could be the fear of making a mistake or of not following instructions as well as other students.

\section{Discussion and Conclusion}

The data that I collected suggested that using visual aids is very helpful for students. Observations and surveys revealed interesting information about the ways teachers and students interact. By analyzing the observation log sheets and students' reflections, I discovered that the major barrier to students' achievement of a higher level of comprehension is the lack of what I like calling "understanding and participation boosters" in the classroom. However, the $\log$ sheet showed that students gained self-confidence gradually and became much more interactive, voluntarily speaking and reading as well. They were not lost or ashamed anymore of reading out loud and participating in the classroom discussion. Studentsbecame much more aware of what they are going to talk about. In addition, by observing the students I pulled out, I realized how engaging the topic that we studied became once I introduced visual aids, scaffolding, and multimedia into the lesson. I realized that in at the beginning, my students were confused and hesitant, until I started drawing and showing those pictures. At that point, they became active speakers instead of simply passive listeners. Moreover, the exercise papers showed that the students started writing more complete sentences, using grammatically correct structures. This proved that even if the idea was a complicated punctuation rule, with visual aids, my students were able to understand the concept even though it was difficult. I was very happy with the results that I saw during my observations, because they proved that visual aids help more than I had anticipated. From my literature review I expected to see a difference, but I did not expect such a difference. The students' attitudes were different; instead of being frustrated by not getting the idea and being left out. They were more involved in speaking, reading and writing. The most important teaching recommendation from the action research is that teachers have to convey information in a clear and explicit way. For instance: for the Halloween lesson, most of the students do not celebrate Halloween and they do not know what its meaning and how they celebrate it by showing them pictures or short clip or even movie to build their background. In general, when the students received support with multimedia during the lessons, they participated more in the classroom discussions and met most of the writing and reading criteria. The delimitations of my action research were the short time period I was given to implement the variables and the limited number of students who participated. Additional research should look to add more time to the study to find out how much the visual aids affect the students' overall performance on a larger scale. Based upon this action research, the inquiry, "Can visual aids improve English language acquisition in reading and writing for a beginner ESL high School student?" was answered in the affirmative. Multimedia and visual aids help beginner ESL middle and high school students in improving English language acquisition in reading and writing very much. As a result of this research, I would strongly recommend the following:

- Teachers should be well trained to use visual aids and the Smart Boards in the classroom to help students to improve their writing skills.

- Opportunities to use books, pictures, and even the web must be provided to the students during the school day for multiple subjects

- Teachers support their students who are interested in researching different topics by utilizing visual aids in a manner that is appropriate for their level of English proficiency. 


\section{References}

Ajayi, L. (2008). Meaning-making, multimodal representation, and transformative pedagogy: An exploration of meaning construction instructional practices in an ESL high school classroom. Journal of Language, Identity, and Education, 7(3-4), 206-229. https://doi.org/10.1080/15348450802237822

Al Tiyb, S. (2014). ESL Elementary Teachers' Use of Children's Picture Books to Initiate Explicit Instruction of Reading Comprehension Strategies. English Language Teaching, 7(2), 90.

Asher, J. J. (1969). The total physical response approach to second language learning. The modern language journal, 53(1), 3-17. https://doi.org/10.1111/j.1540-4781.1969.tb04552.x

Conroy, P. (1999). Total Physical Response: An Instructional Strategy for Second-Language Learners Who Are Visually Impaired. Journal of Visual Impairment \& Blindness, 93(5), 315-318.

Cooper, L. Z. (2002). Considerations in cross-cultural use of visual information with children for whom English is a second language. Journal of Visual Literacy, 22(2), 129-142. https://doi.org/10.1080/23796529.2002.11674585

Cunningham, J. (1991). Making and Using Slides in the ESL Classroom. TESL Canada Journal, 9(1), 67-78. https://doi.org/10.18806/tesl.v9i1.597

Gorman, R., \& Eastman, G. S. (2010). I See What You Mean: Using Visuals to Teach Metaphoric Thinking in Reading and Writing. English Journal, 92-99.

Henry, R., \& Simpson, C. (2001). A match made in heaven. Teacher Librarian, 28(3), 23.

Mohr, K. A. (2004). English as an accelerated language: A call to action for reading teachers. The Reading Teacher, 58(1), 18-26. https://doi.org/10.1598/RT.58.1.2

Park, C. C. (2000). Learning style preferences of Southeast Asian students. Urban Education, 35(3), 245-268. https://doi.org/10.1177/0042085900353002

Shaw, E. L., Baggett, P. V., \& Salyer, B. (2004). Kidspintion ${ }^{\circledR}$ for Inquiry-Centered Activities. Science Activities: Classroom Projects and Curriculum Ideas, 4l(1), 3-8. https://doi.org/10.3200/sats.41.1.3-8

Turner, C. E., \& Upshur, J. A. (1995). Some effects of task type on the relation between communicative effectiveness and grammatical accuracy in intensive ESL classes. TESL Canada Journal, 12(2), 18-31. https://doi.org/10.18806/tesl.v12i2.650

van Berkel, A. (2004). Learning to spell in English as a second language. IRAL, 42, 239-258. https://doi.org/10.1515/iral.2004.012

Van Staden, A. (2011). Put reading first: Positive effects of direct instruction and scaffolding for ESL learners struggling with reading. Perspectives in Education, 29(4), 10-21. 


\section{Appendix 1}

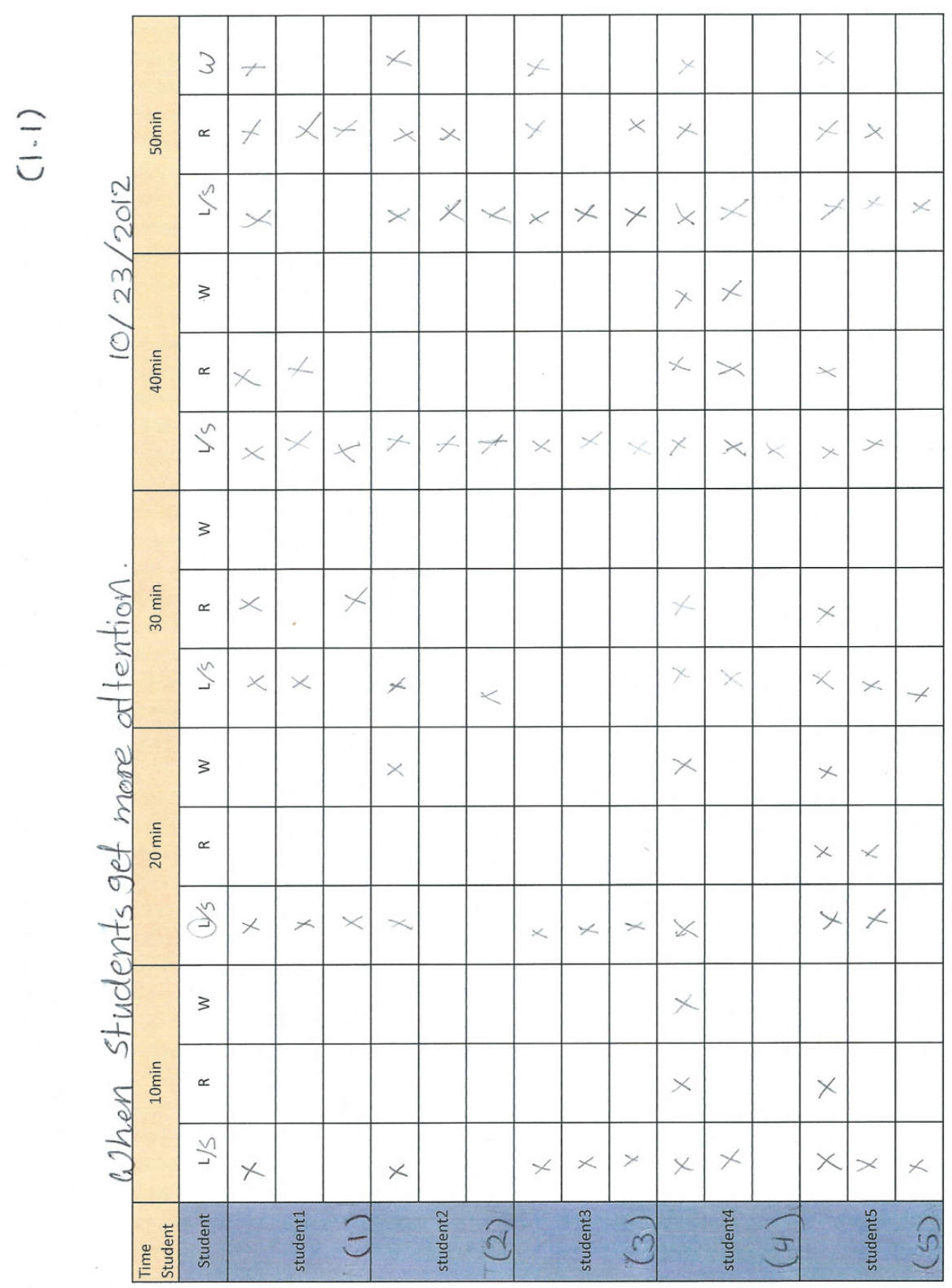




\section{Appendix 2}

$$
(1,2)
$$

Grade: $\int i a$ Gender:

Please fill out the following questionnaire about today's class. The feedback is completely anonymous.

Please choose how much you agree with each statement.

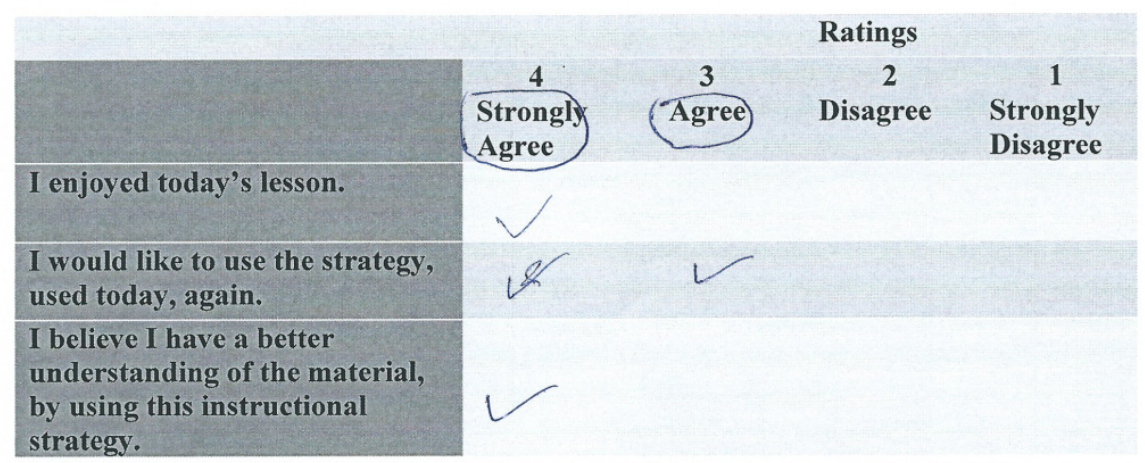

\section{Copyrights}

Copyright for this article is retained by the author(s), with first publication rights granted to the journal.

This is an open-access article distributed under the terms and conditions of the Creative Commons Attribution license (http://creativecommons.org/licenses/by/4.0/). 